\title{
BAIT PREFERENCES BY DIFFERENT SMALL MAMMAL ASSEMBLAGES FOR EFFECTIVE CAGE-TRAPPING
}

\author{
Farah Shafawati Mohd-Taib ${ }^{1 a^{*}}$ and Siti Nabilah Ishak ${ }^{2 a}$
}

\author{
aDepartment of Biological Sciences and Biotechnology, Faculty of Science and Technology, Universiti \\ Kebangsaan Malaysia, 43600, Selangor, MALAYSIA. Email: farah_sh@ukm.edu.my ${ }^{1}$; \\ nabilahishak294@gmail.com² \\ *Corresponding author: farah_sh@ukm.edu.my \\ Received: $10^{\text {th }}$ Jan $2020 \quad$ Accepted: $19^{\text {th }}$ Oct 2020 \\ Published: $30^{\text {th }}$ Jun 2021
}

DOI: https://doi.org/10.22452/mjs.vol40no2.1

\begin{abstract}
The ecological study of small mammals often uses the cage-trapping method, installed with baits. Capture rates vary according to different baits used. We want to determine the bait preferences by different small mammal groups. The cage-trapping approach used common domestic bait types available, namely, aromatic banana, sweet potato with peanut butter, oil palm fruit, dried salted fish, jackfruit, and roasted coconut flesh. Sampling was conducted in three different habitat categories, namely urban, semi-urban, and recreational forests, located in Selangor, Malaysia, for one year. A total of 537 small mammals from 15 species were sampled, which was then grouped into seven groups (i.e., Rattus sp., Maxomys sp., Sundamys sp., Leopaldamys sabanus, Suncus murinus, squirrels, and Tupaia glis). Bait preferences were significantly different among the different small mammal groups, i.e., $\mathrm{F}$ $(6,35)=5.621, \mathrm{p}=0.000$, with bananas shown to be most preferred bait, followed by oil palm fruits and sweet potatoes. Non-metric multidimensional scaling (nMDS) analysis revealed that the Rattus species encompassed the most diverse bait preference, while $S$. murinus and $L$. sabanus were the most selective. Muridae preferred sweet potatoes with peanut butter over bananas, while Sciuridae and Tupaiidae preferred bananas, and Soricidae preferred dried salted fish. This study elucidates the most effective bait selection for different small mammal assemblages, serving as a guide to increase capture rates when sampling targeted population of small mammals. Apart from that, it is helpful for effective rodent pest control.
\end{abstract}

\begin{abstract}
ABSTRAK Kajian ekologi mamalia kecil sering menggunakan kaedah perangkap sangkar, yang dipasang dengan umpan. Kadar tangkapan adalah berbeza-beza mengikut jenis umpan yang berlainan. Kami ingin menentukan pemilihan umpan mengikut kumpulan mamalia kecil yang berlainan. Perangkap sangkar menggunakan jenis umpan domestik yang tersedia iaitu pisang aromatik, ubi keledek manis bersama mentega kacang, buah kelapa sawit, ikan kering masin, buah nangka, dan isi kelapa dibakar. Persampelan dilakukan di tiga kategori habitat yang berlainan iaitu bandar, separa bandar dan hutan rekreasi yang terletak di Selangor, Malaysia dalam tempoh satu tahun. Sejumlah 537 mamalia kecil dari 15 spesies, yang kemudiannya dikumpulkan kepada tujuh kumpulan (Rattus sp., Maxomys sp., Sundamys sp., Leopaldamys sabanus, Suncus murinus, tupai, dan Tupaia glis). Pemilihan
\end{abstract}


umpan adalah sangat berbeza di antara kumpulan mamalia kecil $(\mathrm{F}(6,35)=5.621, \mathrm{p}=0.000)$, dengan pisang menunjukkan umpan yang paling digemari, diikuti oleh buah kelapa sawit dan ubi keledek. Analisis Non-metric multidimensional scaling (nMDS) mendedahkan bahawa spesies Rattus merangkumi pemilihan umpan yang paling pelbagai, manakala Suncus dan Leopaldamys adalah paling selektif. Murridae memilih ubi keledek bersama mentega kacang berbanding pisang. Sciuridae dan Tupaiidae menunjukkan pemilihan terhadap pisang, manakala ikan kering digemari oleh Soricidae. Kajian ini menjelaskan pemilihan umpan yang paling berkesan untuk kumpulan mamalia kecil yang berbeza, dan boleh menjadi panduan untuk meningkatkan kadar penangkapan populasi mamalia kecil yang disasarkan. Selain itu, ia berguna dalam pengawalan perosak tikus yang berkesan.

Keywords: Trapping, baits preference, Rattus, squirrels, scandent, shrew

\section{INTRODUCTION}

Apart from their small size (less than 5 kilograms), some small mammals are known as secretive and nocturnal animals. Some of the species are commensal rats and recognised as notorious pests in the urban environment, causing not only damage to properties but also an important reservoir for several zoonotic pathogens, such as Leptospira, hantavirus, and plague. Small mammal research and rodent pest-control often use cage-trapping method, installed with various bait types to capture the animals. This method enables the estimation of community structure and population density of small mammals; thus, requiring an effective sampling system (Woodman et al., 1996). Cage-trapping is an essential method for estimating the structure, composition, and population size of small mammals (Stokes, 2012), and essential to understanding the ecological health of specific habitats (Schnurr et al., 2004). A high diversity of small mammals indicates a healthy environment, while a low diversity of small mammals may reveal a depauperate habitat (Avenant, 2000; Jorgensen, 2004).
The ecological studies of small mammals have been documented in various habitat types in Malaysia, especially the lowland rainforests (Kemper \& Bell, 1985; Nakagawa et al., 2007; Jayaraj et al., 2012), montane forests (Nor, 2011), islands (Mohd-Taib et al., 2019), semi-urban and urban areas (Yusof et al., 2018; Mohd-Taib et al., 2020). These studies used different baits, including bananas, sweet potatoes, fried coconut, jackfruits, and oil palm fruits. In addition, different habitat types have been shown to encompass different species assemblages of small mammals, as more forested areas exhibit a higher species richness and diversity. Urban areas, on the other hand, exhibit poorer species assemblages, with the domination of commensal species.

It was reported that bait types and trapping protocols such as time, influence the capture rates of small mammals (Hize \& Velazco, 2013). Baits or scented lures are commonly used globally to capture small mammals in different habitats (Kok et al., 2013). A previous study reported that the various baits used in different habitat types could affect the number of individuals and 
species composition of small mammals (Woodman et al., 1996). A vast range of bait types are available for cage-trapping of small mammals, and it differs according to the region. Studies in Indo-China used different types of vegetables, including sticky rice, peanuts, banana, dried fruits, and meat (Starr et al., 2012; Parrot et al., 2014). In New Zealand, researchers have used cheese, chocolate, soap, wax, and oiled wood (Weihong et al., 1999), whereas, in east Asia, minced meat, yeast, fish meal, and egg baits were used (Pervez, 2007). Meanwhile, most studies in Malaysia used banana, papaya, sweet potato, coconut, oil palms, jackfruits, dried fish (Mariana et al., 2005; Bernard et al., 2009; Lee \& Goh, 2000; Ishak et al., 2018; Yusof et al., 2019) and even fresh prawns (Hafidzi, 2007) and anchovies (Zakaria et al., 2001). Amni et al. (2019) reported that fried chicken has a high capture rate compared to the other baits, indicating that high protein bait is the most attractive bait for commensal rats in urban areas.

According to Woodman et al. (1996), bait is one of the factors that affect the ability to capture small mammals. It has been shown that different species of small mammals have different bait preferences (Oswald \& Flake, 1994), and they require specific baits to be efficiently captured (Stickel, 1948). Knowledge of bait preferences is essential to increase the capture rate of target species (Amni et al., 2019). The trapping success is also affected by the availability of food in the surrounding field, as abundant food resources might reduce the chance of being captured, especially if the bait type used are readily available in the surrounding area (Aplin et al., 2003). Besides, baits provide support and maintenance for trapped animals; thus, reducing the possibilities of trap mortality (Jones et al., 1996), unlike other trapping methods such as snap trap and poison bait, which kill the animals upon contact. Besides, determining the specific bait types to a target population would be the most effective approach for cagetrapping. Therefore, the study aims to assess the bait preferences of different small mammal assemblages. In this study, we include a vast array of small mammal assemblages through a year-long sampling, in different habitat types. This finding would be useful for effective rodent control, as well as optimising the ecological sampling of small mammals.

\section{MATERIALS AND METHODS}

\subsection{Study Areas}

The research was carried out from January 2016 to May 2017 in three different habitat types located in Selangor, Malaysia (Figure 1; Table 1). The sites were classified as urban, semi-urban, and recreational forests. Urban areas are rated as the extremely populated provision of adequate living conditions, infrastructure, and facilities (Hassan et al., 2013; MohdTaib et al., 2020). Semi-urban areas typically constitute human settlements with less concentrated populations than the urban areas, while recreational forest serves as nature outdoor spots for visitors (Yusof et al., 2018). 


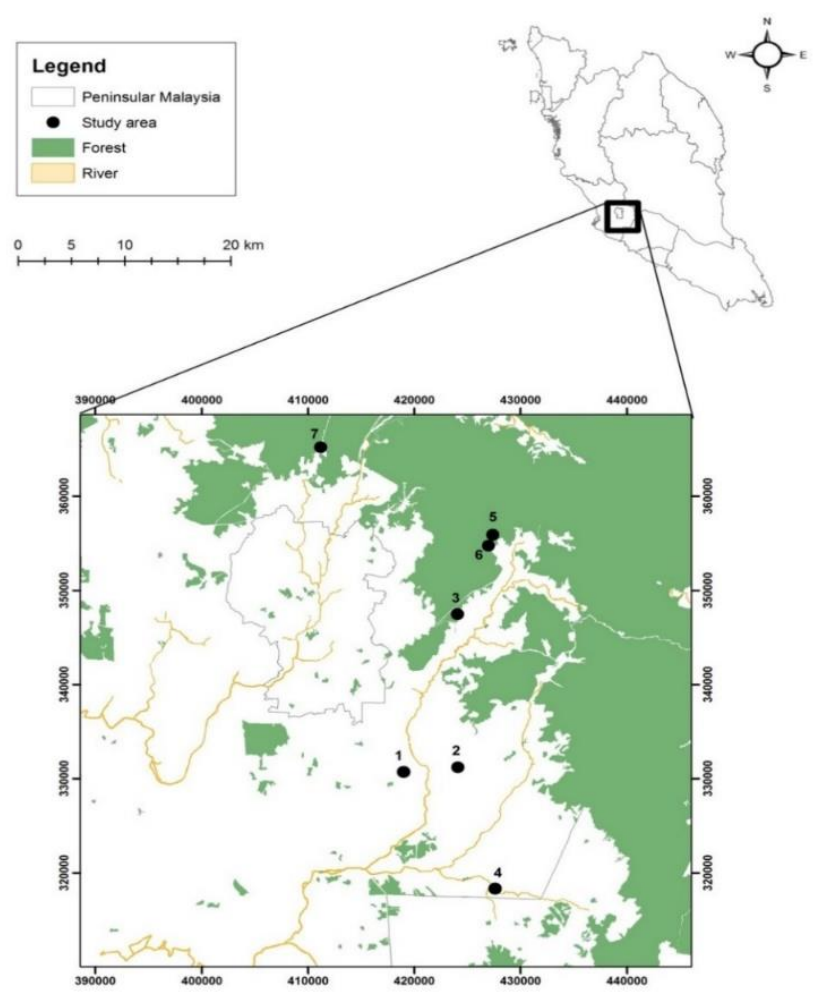

Figure 1. Location of the study sites in Selangor state, Malaysia

Table 1. Study sites according to the habitat categories

\begin{tabular}{llccc} 
& \multicolumn{1}{c}{ Study sites } & Habitat & & \multicolumn{2}{c}{ GPS coordinate } \\
\cline { 4 - 4 } & & category & N reading & E reading \\
\hline 1 & Sungai Ramal Baru, Kajang & Urban & $02^{\circ} 59^{\prime} 17.9^{\prime \prime}$ & $101^{\circ} 45^{\prime} 56.0^{\prime \prime}$ \\
2 & Taman Sri Jelok, Kajang & Urban & $02^{\circ} 59^{\prime} 33.0^{\prime \prime}$ & $101^{\circ} 48^{\prime} 46.0^{\prime \prime}$ \\
3 & $\begin{array}{l}\text { Kg. Sg. Semungkis, Hulu } \\
\text { Langat }\end{array}$ & Semi-urban & $03^{\circ} 08^{\prime} 18.7^{\prime \prime}$ & $101^{\circ} 48^{\prime} 41.2^{\prime \prime}$ \\
4 & $\begin{array}{l}\text { Kem PLKN Millennium } \\
5\end{array}$ & $\begin{array}{c}\text { Semi-urban } \\
\text { Sg. Congkak, Hulu Langat }\end{array}$ & $02^{\circ} 52^{\prime} 35.1^{\prime \prime}$ & $101^{\circ} 50^{\prime} 36.8^{\prime \prime}$ \\
& $\begin{array}{c}\text { Recreational } \\
\text { forests }\end{array}$ & $03^{\circ} 12^{\prime} 35.7^{\prime \prime}$ & $101^{\circ} 50^{\prime} 35.3^{\prime \prime}$ \\
6 & $\begin{array}{l}\text { Sg. Hulu Perdik, Hulu } \\
\text { Langat }\end{array}$ & $\begin{array}{c}\text { Recreational } \\
\text { forests }\end{array}$ & $03^{\circ} 12^{\prime} 18.1^{\prime \prime}$ & $101^{\circ} 50^{\prime} 10.0^{\prime \prime}$ \\
\hline & $\begin{array}{l}\text { Sg. Tua, Ulu Yam, Hulu } \\
\text { Selangor }\end{array}$ & $\begin{array}{c}\text { Recreational } \\
\text { forests }\end{array}$ & $03^{\circ} 18^{\prime} 02.9^{\prime \prime}$ & $101^{\circ} 41^{\prime} 42.4^{\prime \prime}$ \\
\hline
\end{tabular}




\section{$2.2 \quad$ Fieldwork Sampling}

Small mammal sampling involved deploying 100 cage traps $(16 \times 16 \times 50 \mathrm{~cm})$ randomly with at least a 10 -meter distance to one another, at each study site. The cage traps were located on the ground along the forest trails, river, and around residential houses. The animals were baited with different bait types, which include aromatic banana, sweet potato with peanut butter, oil palm fruits, dried salted fish, jackfruits, and roasted coconut flesh. The cages with different baits were placed interspersed between each other fairly equally (Fig. 2). All cage traps were left open overnight and during the day to increase the chances of capturing nocturnal and diurnal species (Kok et al., 2013). Traps were checked once daily in the morning (10:00 hour) and stolen, or damaged baits were replaced with a new one. Sampling was conducted in two phases, in alternate months at each site throughout the sampling period. Trapping was carried out for six days and five nights for each phase.

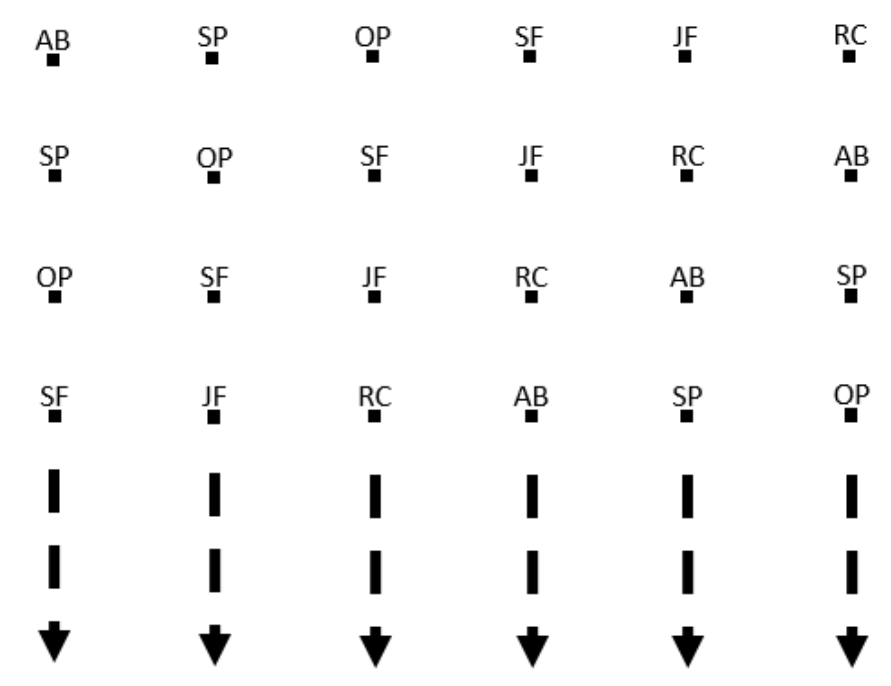

Figure 2. Cage with different baits placements interspersed with each other (Note: black squares referred to cages, baited with varying types of bait; $\mathrm{AB}=$ aromatic bananas; $\mathrm{SP}=$ sweet potato; $\mathrm{OP}=$ oil palm fruits; $\mathrm{SF}=$ salted fishes; JF = Jackfruits; $\mathrm{RC}=$ roasted coconut)

Trapped animals were taken to the research station for examination. Morphological data such as species, sex (male or female), age classes (adult, subadult, or juvenile), health conditions (good, fair, or poor), reproductive conditions (pregnant or non-pregnant), bait preferences, and morphometric measurement data, including body weight, head and body length, tail length, hindfoot, and ear length were recorded. Each small mammal was identified morphologically according to recorded measurements and graphic illustrations, as described by Francis (2008). All captured animals were anaesthetised with an intramuscular injection of Zoletil®100 (Massolo et al., 2003) from $0.02 \mathrm{~mL}$ up to $0.05 \mathrm{~mL}$ depending on the weight of the animals (King et al., 2011) and returned to their captured sites. This study has been approved by the animal research Ethics 
Committee at Universiti Kebangsaan Malaysia (FST/2016/SHUKOR/18MAY/750-MAY-2016-SEPT.-2018-ARCAT2).

\subsection{Data Analyses}

Normality test was first performed to determine the distribution of the mean (normal distribution via Shapiro-Wilk test; $p>0.05$ ). A two-way ANOVA (without replication) was performed to determine the main effects contributing to the food preference among the small mammals captured. A one-way ANOVA was then performed to determine if there is a significant difference between the bait types and small mammal groups on bait preferences, followed by a Tukey post-hoc test to distinguish the significant difference of each factor. This analysis was performed using SPSS software version 23 (IBM Corporation). A gradient analysis approach, non-metric multidimensional scaling (nMDS), which produces an ordination based on a distance or dissimilarity matrix, was also presented based on the BrayCurtis index to demonstrate the pattern of food preference by different small mammal species assemblages. Prior to this analysis, one-way permutational analysis of variance (PERMANOVA) was adopted to calculate the effect of different environmental factors and interactions in shaping the food preference among the small mammals. This analysis was performed using PAST version $2.17 \mathrm{c}$ downloaded from (http://folk.uio.no/ohammer/past).

\section{$2.4 \quad$ Results}

\subsubsection{Species assemblages and abundance of small mammals at different habitat categories}

During this study, 537 individuals of small mammals comprising of three orders (Insectivora, Scandentia, and Rodentia), four families (Muridae, Sciuridae, Tupaiidae, and Soricidae) and 15 species were captured in three habitat categories, as shown in Table 2. The urban areas recorded a higher number of individuals $(n=226)$ compared to the semiurban $(\mathrm{n}=189)$ and recreational forests ( $\mathrm{n}$ $=122$ ). The largest and most dominant family recorded in all three habitats was Muridae (437 individuals, 8 species), composed of $84 \%$ of the total number of small mammals captured, followed by Sciuridae (23 individuals, 5 species), Tupaiidae (53 individuals, 1 species), and Soricidae (7 individuals, 1 species). However, the semi-urban areas recorded the highest number of species (13 species), followed by the recreational forests (11 species), and the lowest was in the urban areas (4 species).

Based on Table 2, the most abundant and common species captured was Rattus norvegicus ( $\mathrm{n}=155)$, followed by Rattus rattus ( $\mathrm{n}=100)$, Maxomys whiteheadi, $(\mathrm{n}=68)$, and Rattus tiomanicus $(\mathrm{n}=66)$. Meanwhile, the least captured was Maxomys surifer $(\mathrm{n}=2)$, Callosciurus caniceps $(\mathrm{n}=2)$, and Lariscus insignis, $(\mathrm{n}$ $=1$ ). The urban areas were dominated by $R$. norvegicus $(\mathrm{n}=149)$ and $R$. rattus $(\mathrm{n}=52)$. In contrast, the semi-urban areas were dominated by $R$. tiomanicus $(\mathrm{n}=55), R$. rattus $(\mathrm{n}=34)$, and Tupaia glis $(\mathrm{n}=28)$, whereby recreational forests were dominated by $M$. whiteheadi $(\mathrm{n}=41)$ and Sundamys muelleri $(\mathrm{n}=26)$. Three species were found in all three habitats, namely $R$. norvegicus, $R$. rattus, and $T$. glis. Both semi-urban and recreational forests shared nine species of small mammals $(M$. whiteheadi, $R$. tiomanicus, $R$. rattus, $S$. muelleri, Leopaldamys sabanus, $R$. norvegicus, Maxomys rajah, T. glis, and Sundasciurus lowii). 
Table 2. Number of small mammal individuals captured at the three habitat categories

\begin{tabular}{|c|c|c|c|c|c|c|}
\hline \multirow{2}{*}{ Family } & \multirow{2}{*}{ Species } & \multirow{2}{*}{$\begin{array}{l}\text { Common } \\
\text { Name }\end{array}$} & \multicolumn{3}{|c|}{ Habitat category } & \multirow{2}{*}{ Total } \\
\hline & & & Urban & $\begin{array}{l}\text { Semi- } \\
\text { urban }\end{array}$ & $\begin{array}{c}\text { Recreational } \\
\text { forests }\end{array}$ & \\
\hline \multirow{8}{*}{ Muridae } & Rattus norvegicus & Norway rat & 149 & 4 & 2 & 155 \\
\hline & Rattus rattus & Black rat & 52 & 34 & 14 & 100 \\
\hline & Rattus tiomanicus & Wood rat & 0 & 55 & 11 & 66 \\
\hline & $\begin{array}{l}\text { Maxomys } \\
\text { whiteheadi }\end{array}$ & $\begin{array}{l}\text { Whitehead's } \\
\text { spiny rat }\end{array}$ & 0 & 27 & 41 & 68 \\
\hline & Maxomys rajah & $\begin{array}{l}\text { Rajah's spiny } \\
\text { rat }\end{array}$ & 0 & 2 & 6 & 8 \\
\hline & Maxomys surifer & Red's spiny rat & 0 & 0 & 2 & 2 \\
\hline & Sundamys muelleri & $\begin{array}{l}\text { Muller's Giant } \\
\text { Sunda rat }\end{array}$ & 0 & 18 & 26 & 44 \\
\hline & $\begin{array}{c}\text { Leopoldamys } \\
\text { sabanus }\end{array}$ & $\begin{array}{c}\text { Long-tailed } \\
\text { Giant rat }\end{array}$ & 0 & 2 & 9 & 11 \\
\hline \multirow[t]{5}{*}{ Sciuridae } & $\begin{array}{c}\text { Callosciurus } \\
\text { notatus }\end{array}$ & $\begin{array}{c}\text { Plaintain } \\
\text { squirrel }\end{array}$ & 0 & 12 & 0 & 12 \\
\hline & $\begin{array}{c}\text { Callosciurus } \\
\text { caniceps }\end{array}$ & $\begin{array}{l}\text { Grey-bellied } \\
\text { squirrel }\end{array}$ & 0 & 2 & 0 & 2 \\
\hline & Sundasciurus lowii & Low's squirrel & 0 & 1 & 3 & 4 \\
\hline & $\begin{array}{c}\text { Sundasciurus } \\
\text { tenuis }\end{array}$ & $\begin{array}{l}\text { Slender } \\
\text { squirrel }\end{array}$ & 0 & 0 & 4 & 4 \\
\hline & Lariscus insignis & $\begin{array}{c}\text { Three-striped } \\
\text { squirrel }\end{array}$ & 0 & 1 & 0 & 1 \\
\hline Tupaiidae & Tupaia glis & $\begin{array}{l}\text { Common } \\
\text { treeshrew }\end{array}$ & 21 & 28 & 4 & 53 \\
\hline Soricidae & Suncus murinus & House shrew & 4 & 3 & 0 & 7 \\
\hline TOTAL & & & 226 & 189 & 122 & 537 \\
\hline
\end{tabular}

\subsubsection{Baits preferences among small mammal groups}

Overall, traps baited with aromatic banana caught the highest number of individuals $(\mathrm{n}=183,11$ species $)$, followed by sweet potato and peanut butter $(\mathrm{n}=143$, 10 species $)$, and oil palm fruits $(\mathrm{n}=141,11$ species), as shown in Table 3. Small mammal showed a poor response towards jackfruits ( $\mathrm{n}=7,4$ species) and roasted coconut flesh ( $n=4,1$ species). The trends in baits selection among small mammals can be seen between four groups of family, Muridae, Sciuridae, Tupaiidae, and Soricidae. Muridae, which comprised of four groups (Rattus sp., Maxomys sp., Sundamys sp., and L. sabanus), preferred sweet potato with peanut butter over the banana. Meanwhile, Sciuridae (squirrels) 
group (Sundasciurus, Callosciurus, and Lariscus) and Tupaiidae (T. glis) showed a high preference on aromatic banana, while dried salted fish became the first choice of Soricidae group (Suncus murinus). From this result, it can be proven that Rattus sp. and Sundamys sp. groups were composed of more diverse bait preferences, followed by Maxomys sp. and L. sabanus. Specialised bait preferences were more apparent, especially in S. murinus, followed by $T$. glis and squirrels.

Table 3. The total number (and percentage) of captures for each small mammal species with different bait types

\begin{tabular}{ccccccc}
\hline Species & Banana & $\begin{array}{c}\text { Peanut } \\
\text { butter }\end{array}$ & $\begin{array}{c}\text { Oil palm } \\
\text { fruits }\end{array}$ & $\begin{array}{c}\text { Dried } \\
\text { salted fish }\end{array}$ & Jackfruits & Coconut \\
\hline Rattus norvegicus & $51(33)$ & $60(38.9)$ & $9(5.84)$ & $31(20)$ & - & $4(2.59)$ \\
\hline Rattus rattus & $\begin{array}{c}29 \\
(28.7)\end{array}$ & $28(27.7)$ & $24(23.7)$ & $19(18.8)$ & - & - \\
\hline Rattus tiomanicus & $\begin{array}{c}17 \\
(25.7)\end{array}$ & $16(24.2)$ & $31(46.9)$ & $2(3.03)$ & - & - \\
\hline $\begin{array}{c}\text { Maxomys } \\
\text { whiteheadi }\end{array}$ & $\begin{array}{c}10 \\
(14.7)\end{array}$ & $15(22)$ & $40(60.6)$ & - & $3(4.4)$ & - \\
\hline $\begin{array}{c}\text { Maxomys rajah } \\
4(50)\end{array}$ & $1(1.47)$ & $3(37.5)$ & - & - & - \\
\hline $\begin{array}{c}\text { Maxomys surifer } \\
\text { Sundamys } \\
\text { muelleri }\end{array}$ & - & - & - & $1(50)$ & $1(50)$ & - \\
\hline $\begin{array}{c}\text { Leopoldamys } \\
\text { sabanus }\end{array}$ & $4(38.6)$ & $14(31.8)$ & $10(22.7)$ & $2(4.54)$ & $1(2.27)$ & - \\
\hline
\end{tabular}

\section{Family Sciuridae}

\begin{tabular}{ccccccc}
\hline $\begin{array}{c}\text { Callosciurus } \\
\text { notatus }\end{array}$ & $9(75)$ & - & $3(25)$ & - & - & - \\
\hline $\begin{array}{c}\text { Callosciurus } \\
\text { caniceps }\end{array}$ & - & - & $2(100)$ & - & - & - \\
\hline $\begin{array}{c}\text { Sundasciurus } \\
\text { lowii }\end{array}$ & $2(50)$ & $2(50)$ & - & - & - & - \\
\hline $\begin{array}{c}\text { Sundasciurus } \\
\text { tenuis }\end{array}$ & - & - & $2(50)$ & - & $2(50)$ & - \\
\hline
\end{tabular}

Lariscus insignis $1(25)$

Family Tupaiidae

\begin{tabular}{ccccccc}
\hline \multicolumn{1}{c}{ Tupaia glis } & 39 & $3(5.66)$ & $11(20.7)$ & - & - & - \\
\hline \multicolumn{7}{c}{ Family Soricidae } \\
\hline \multirow{2}{*}{ Suncus murinus } & - & 3 & - & $4(57)$ & - & - \\
\hline \multirow{2}{*}{ TOTAL } & 183 & \multirow{2}{*}{$143(26.6)$} & $(26.3)$ & $(10.8)$ & $(1.3)$ & $(0.9)$ \\
\hline
\end{tabular}


A two-way ANOVA without replication was carried out to determine if the bait preferences were different among small mammal groups $(n=7)$ and bait types $(\mathrm{n}=6)$. Small mammals were grouped into Rattus sp. $(\mathrm{n}=321)$, Maxomys $\mathrm{sp} .(\mathrm{n}=78)$, Sundamys sp. $(\mathrm{n}=44)$, L. sabanus $(\mathrm{n}=11)$, S. murinus $(\mathrm{n}=7)$, squirrels (Sciuridae; $\mathrm{n}=$ 23), and T. glis $(\mathrm{n}=53)$. The data were normally distributed for each group, as assessed by the Shapiro-Wilk test ( $p$ > $0.05)$. There was a significant difference in food preference for small mammal groups
$(\mathrm{F}=7.178, \mathrm{dF}=6, p=0.000)$ and bait types $(\mathrm{F}=2.937, \mathrm{dF}=5, p=0.0283)$. However, one-way ANOVA of food preference was only significantly different for small mammal groups $(\mathrm{F}[6,35]=5.621, p=$ $0.000)$, but not for bait types $(\mathrm{F}[5,36]=$ $1.447, p=0.231)$. For small mammal group, Tukey post-hoc analysis revealed that food preferences of Rattus sp. groups were significantly different with other small mammal groups $(p<0.05)$, but no significant difference among other groups (Figure 3).

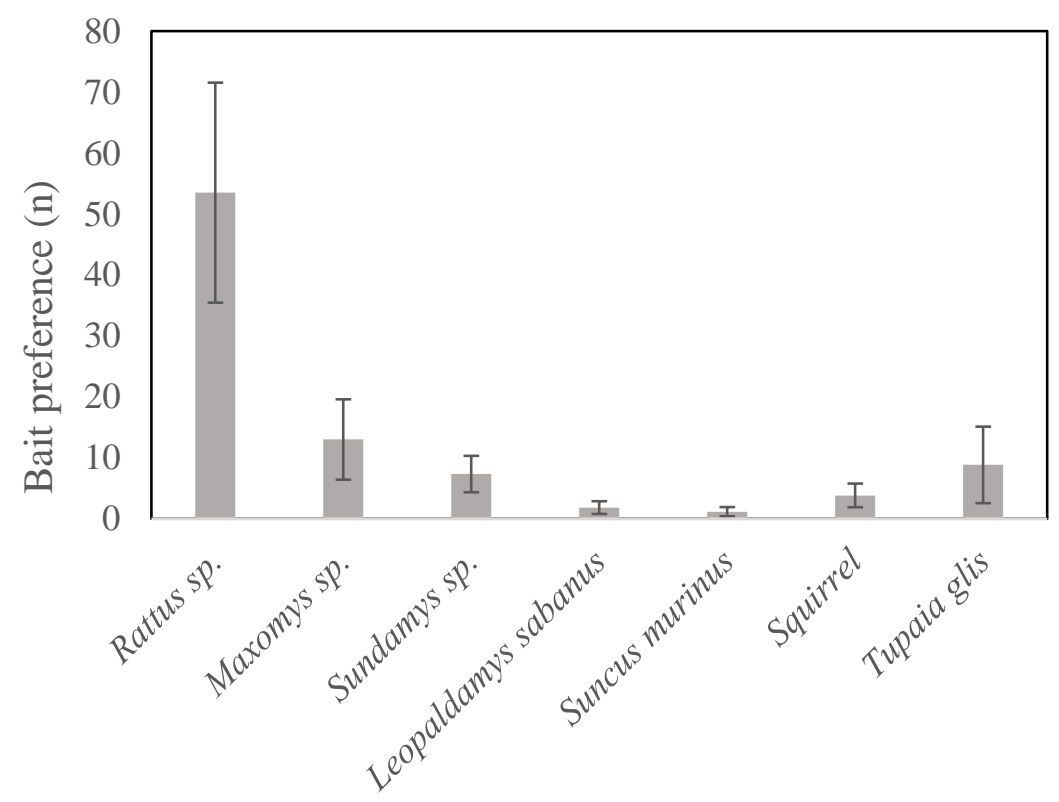

Small mammal groups

Figure 3. Mean \pm SE of bait preferences for each small mammal group.

The nMDS ordination based on the food preference reveals different pattern among small mammals (Figure 4). A stress value of 0.06 ( 0.05 to 0.1$)$ is considered a fair representation of the model. Rattus group showed the biggest convex hulls polygon, indicating the most diverse bait selection, with the highest overlapping points with Maxomys sp. and Sundamys sp. Meanwhile, S. murinus showed the most non-overlapping points, indicating a highly distinct bait preference compared to the other groups. One-way PERMANOVA analyses showed that there were no significant differences in food preference among the different small mammal groups (PERMANOVA, $\mathrm{F}=1.347, \quad p=0.179$ ). However, for pair-wise comparison, $L$. sabanus and $S$. murinus showed a significant difference with Rattus sp. preferences with $p=0.0245$ and $p=0.016$ respectively. Other small mammal groups did not show a significant difference in the bait preference to Rattus ( $p>0.05$ ). This can be further explained by the cumulative percentage of bait preference among 
different small mammal groups (Figure 5). As explained earlier, the Rattus sp. encompassed the most diverse food preference, followed by Maxomys sp. and Sundamys sp. In contrast, S. murinus preferred minimal bait types, i.e., dried fish and sweet potato with peanut butter.
In terms of bait selections, banana was found to be the most preferred bait, followed by sweet potato with peanut butter, and oil palm fruits. Tupaia and squirrel groups preferred highly on banana compared to other bait types.

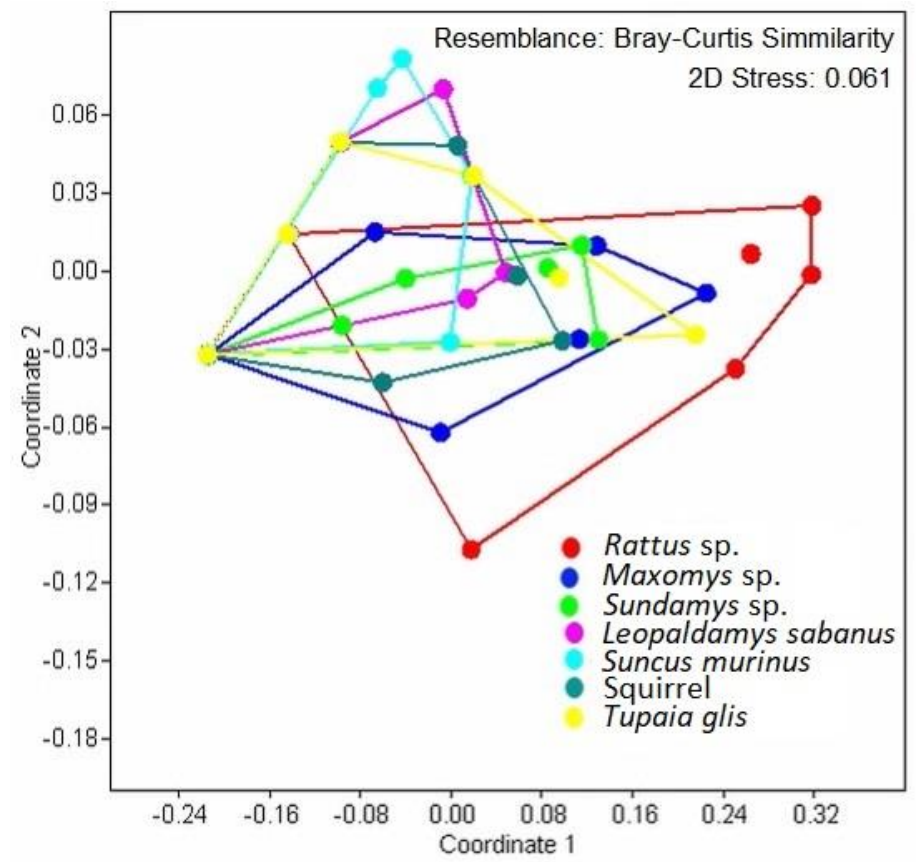

Figure 4. Non-metric multidimensional scaling (nMDS) ordinations of bait preference among the different group of small mammals with convex hulls polygon representing different groups.

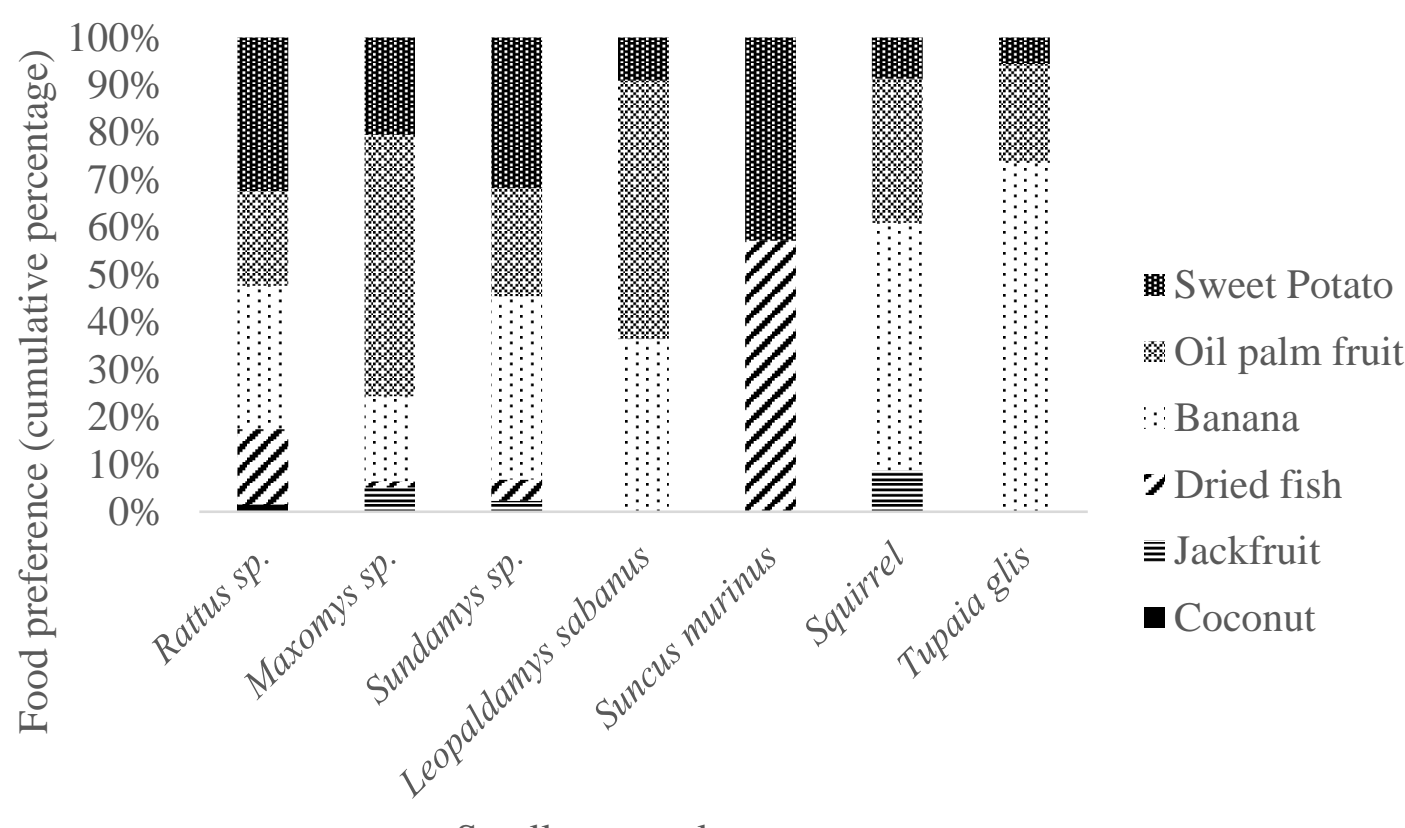

Small mammal groups

Figure 5. Cumulative percentage of bait preferences among different small mammal groups 


\section{DISCUSSION}

This present study of small mammals in three habitat types allowed us to evaluate how different bait types used during cage-trapping affects the total number of captured small mammals and the effectiveness of each bait type used. Our results indicate that bait preferences differ significantly among different small mammal assemblages. Rattus sp. group showed the most diverse bait preferences, followed by Maxomys sp. and Sundamys sp. In contrast, $S$. murinus showed a very limited range of bait preference. Apart from that, there were distinct bait preferences among rodents (except squirrel) and scandent (Tupaia), whereby rodents preferred oil palm fruits, followed by banana and sweet potato with peanut butter. In contrast, squirrels and scandent preferred banana over oil palm fruits.

Aromatic banana caught more small mammals (34\%) than other bait types. This finding is in agreement with the research work done by Zakaria et al. (2001) and Md. Nor (2001), who reported that banana was the most effective bait in capturing small mammal. However, even though banana caught more individual and species overall, the trends in bait preferences vary among different small mammal groups (Bernard, 2003). For instance, Muridae, the largest small mammal group captured with 8 species, showed $51 \%$ of the total individual preferred sweet potato with peanut butter over banana. Previous research indicated that a trap baited with peanut butter has a positive effect on the success of capturing small mammal (Kumar et al., 2013). Previously, Beer (1964) and Patric (1970) indicated the preference of peanut butter as bait in trapping small mammals. Beer (1964) discovered that peanut butter mixed with rolled oats was preferred over other baits, whereas Patric (1970) proved that peanut butter was preferred over all other baits, including meat baits. In addition, Manville et al. (1992) revealed that white- footed mouse (Peromyscus leucopus) climbed the trees that were marked with peanut butter and proved significantly that $P$. leucopus were lured into trees by baits. Furthermore, baits such as sweet potato, banana, oats, and coconut coated or mixed with peanut butter may provide additional and strong smell to attract a variety of small mammal groups (Harkins et al., 2019). Besides, Bernard (2003) found that mixed bait caught almost two times the number of small mammals compared with single baits type. However, Kumar et al. (2013) discovered that the disadvantage of using peanut butter as bait is that it attracted other animals that either crushed or destroyed the traps or carried it away.

Nonetheless, Rattus species was shown to exhibit the most diverse bait preference compared to the other small mammal groups. These species, particularly $R$. norvegicus and $R$. rattus are geographically widespread and reach maximum population densities in urban areas where there are plenty of food sources (Glass et al., 1989). Due to their commensal behaviour, these species possibly tend to diversify their diet intake, especially common in households such as peanut butter, banana, dried salted fish etc. Many studies have indicated their attractiveness to flavoured baits, especially loaded with poison for pest control effort (Pervez, 2007; Shafi et al., 2008; Schlötelburg et al., 2018). Apart from that, these species were also known to be cautious, favour the familiarity with a known environment, and eat only small quantities of new foods (Patergnani et al., 2010). Unlike these two species, the conspecific $R$. tiomanicus was not recorded from the urban areas, instead primarily found in the secondary forest and the agricultural areas (Payne et al., 1985). Therefore, diversification of bait types potentially increases the trapping success of the Rattus species. Sundamys sp. and Maxomys sp. exhibited the next most diverse bait preferences. These two species are commonly found in semi-urban and 
near forest fringe. These habitats were usually located at some residential houses, as well as recreational areas, which introduced various food sources from human consumption and others, unlike their typical diets, which composed of insects, fruits, leaves, shoots and other vegetable matter (Yusof et al., 2019). Therefore, explaining the preferences of these species towards the introduced baits such as sweet potato with peanut butter, dried fish, and banana.

Our study also showed the Family Sciuridae (tree squirrels), and Tupaiidae (ground squirrel) preferred banana (52\%) and oil palm fruits (30\%) over other baits. In general, this group is categorised as omnivores, which are insects, fruits, and vegetable feeders (Francis, 2008; Charles \& Ang, 2010). Plantain squirrel (Callosciurus notatus) was found higher in semi-urban areas compared with the other four squirrel species. Studies on the stomach contents of this species revealed that insect was the primary food item, followed by oil palm fruits (Hafidzi, 1998). Similarly, over 70\% of treeshrew ( $T$. glis) captured in this study also preferred banana and oil palm fruits. Aromatic banana is the most effective bait to attract squirrels and treeshrews (Charles \& Ang, 2010). However, Fitch (1954) claimed that it is notoriously difficult to capture certain groups of small mammals, such as house shrews. The only species of Soricidae group captured in this study was $S$. murinus, which only took dried salted fish and sweet potato with peanut butter as baits. Rahelinirina et al. (2017) used dried fish and onion, while Lee (1997) used sweet potato with peanut butter to sample small mammals in human habitation and recorded a high abundance of house shrews compared to other rat species.

Lim (2015) mentioned that a careful selection of baits might increase the number of animals captured concerning the type of habitats sampled. Earlier, Patric (1970) suggested that the perfect bait for small mammals should be appealing enough to catch relatively large numbers of small mammal species. Amni et al. (2019) indicated that protein-based items were most favoured by rats, especially among commensal rodents. Another thing to note is for an appropriate rodent control plan to take place, the first thing to do is to reduce the alternative food sources that may influence the bait preference. Recently, Takacs et al. (2018) developed a new food bait containing synthetic, long-range volatile food attractants that represent rodent's favourite foods that successfully attracted rodents. They proved that the modified baits enabled rodent trapping to be more effective compared to commercial baits such as peanut butter. The use of attractants from household materials as used in this study could overcome the problem of bait-shyness and neophobic among targeted rodent population.

\section{CONCLUSION}

This paper suggests that different bait types had an effect on the capture rate of various small mammal groups, in which different groups of small mammals showed varied preferences towards different bait types. The information on bait preferences by various small mammal groups could serve as a guide on which bait types to use for distinct habitat types, concerning the small mammal assemblages present. Therefore, it proved that bait types are an important factor to be considered for small mammal population sampling, as well as rodent pest control. Other factors to consider for future study are the environmental factors that might directly influence bait consumption; thus, may affect the rodent control plan that has been carried out, such as the placement of the baited traps, the existence of predators and food competitors, and weather conditions. Therefore, determination of the most effective bait types is essential for constructing a specific 
condition where rodent control effort is targeted.

\section{ACKNOWLEDGEMENTS}

We would like to thank the Department of Wildlife and National Park for allowing this research to be conducted. We also convey our sincere gratitude to our lab assistant Abdul Rashid Yaacob for his assistance during the sampling period. This study was partly funded by the Ministry of Higher Education of Malaysia (FRGS/1/2018/STG03/UKM/02/1).

\section{REFERENCES}

Amni WN., Ravindran S., Saufi S., Hamid NH., Zainal-Abidin CMR., Ahamad AH. \& Salim, H. (2019). Commensal Small Mammal Species and Bait Preferences in Urban Areas of Penang Island. Malaysia Journal of Science 38(2): 18-30.

Aplin, K.P., Brown, P.R., Jacob, J., Krebs, C.J. \& Singleton, G.R. (2003). Field methods forrodent studies in Asia and the Indo-Pacific, pp 223, ACIAR Monograph 100 ACIAR, Canberra.

Avenant NL. (2000). Small mammal community characteristics as indicators of ecological disturbance in the Willem Pretorius Nature Reserve, Free State, South Africa. African Journal of Wildlife Research 30(1): 26-33.

Beer JR. (1964). Bait preferences of some small mammals. Journal of Mammalogy 45(4): 632-634.

Bernard H. (2003). Bait preferences of some Small Mammal Species of North Borneo based on Linetrapping with Wire-mesh Live Cage Traps. Sabah Parks Nature 6: 27-44.

Charles JK. \& Ang BB. (2010). Non-volant small mammal community responses to fragmentation of
Kerangas forests in Brunei Darussalam. Biodiversity Conservation 19:543-561.

Fitch HS. (1954). Seasonal acceptance of bait by small mammals. Journal of Mammalogy 35:39-47.

Francis, C.M. (2008). A Field Guide to the Mammals of South-east Asia, pp 392, London, UK: New Holland Publishers.

Glass, G.E., Childs, J.E., Korch, G.W. \& LeDuc, J.W. (1989). Occasional Papers of the Museum of Natural History. Lawrence, Kansas: University of Kansas; Comparative ecology and social interactions of Norway rat (Rattus norvegicus) populations in Baltimore, Maryland, pp 130.

Hafidzi MN, Zakry FAZ. \& Saadiah A. (2007). Ectoparasites of Rattus sp. from Petaling Jaya, Selangor, Malaysia. Pertanika Journal of Tropical Agriculture Science 30(1): 11-16.

Harkins KM, Keinath D. \& Ben-David M. (2019). It's a trap: Optimizing detection of rare small mammals. PLoS ONE 14(3): e0213201.

Hize CL. \& Velazco PM. (2013). Relative Effectiveness of Several Bait and Trap Types for Assessing Terrestrial Small Mammal Communities in Neotropical Rainforest. Occasional Papers Museum of Texas Tech University, pp 316.

Ishak SN, Yusof MA, Md. Nor S, MohdSah SA, Lim FS, Khoo JJ. \& MohdTaib FS. (2018). Prevalence of onhost ticks (Acari: Ixodidae) in small mammals collected from forest near to human vicinity in Selangor, Malaysia. Systematic \& Applied Acarology 23(8): 1531-1544.

Jones C, McShea WJ, Conroy MJ. \& Kunz TH. (1996). Capturing mammals. In: Measuring and Monitoring Biological Diversity, Standard Methods for Mammals, (eds) D.E. 
Wilson, F.R. Cole, J.D. Nichols, R. Rudran \& M.S. Foster, pp. 115155. Smithsonian Institution Press, Washington.

Jorgensen EE. (2004). Small Mammal Use of Microhabitat Reviewed. Journal of Mammalogy 85(3): 531-539.

Kemper, C, \& Bell, D. (1985). Small mammals and habitat structure in lowland rain forest of Peninsular Malaysia. Journal of Tropical Ecology 1(1): 5-22.

King WJ, Wilson ME, Allen T, FestaBianchet M. \& Coulson G. (2011). A capture technique for freeranging eastern grey kangaroos (Macropus giganteus) habituated to humans. Australian Mammalogy 33: 47-51.

Kok AD, Parker DM. \& Barker NP. (2013) Rules of Attraction: The role of bait in small mammal sampling at high altitude in South Africa. African Zoology 48: 84-95.

Kumar AV, Linzey DW. \& Smith CR. (2013). Bait Preferences and Population Status of Small Mammals in Great Smoky Mountains National Park. Journal of the North Carolina Academy of Science 192 (2): 44-52.

Lee CH. \& Goh HS. (2000). Rodent species in mangosteen intercropped with coconuts and their bait preferences. Journal of Tropical Agriculture and Foundation Science 28(1): 31-37.

Lee LL. (1997). Effectiveness of Live Traps and Snap Traps in Trapping Small Mammals in Kinmen. Acta Zoologica Taiwanica 8(2): 79-85.

Lim BL. (2015). The field rats and field mouse in Malaysia and Southeast Asia. UTAR Agriculture Science Journal 1(3).

Manville CJ, Barnum SA. \& Tester JR. (1992). Influence of Bait on Arboreal Behaviour of Peromyscus leucopus. Journal of Mammalogy 73(2): 335-336.
Massolo A, Sforzi A. \& Lovari S. (2003). Chemical immobilization of crested porcupines with tiletamine $\mathrm{HCl}$ and zolazepam $\mathrm{HCl}$ (Zoletil) under field conditions. Journal of Wildlife Diseases 39: 727-731

Mohd-Taib FS, Ishak SN, Yusof MA, Azhari NN, Md-Lasim A, Md. Nor S, Mohd-Sah SA \& Neela VK (2020). Leptospirosis: An insight into community structure of small mammal's host in urban environment. Tropical Biomedicine 37(1): 142-154

Mohd-Taib FS, Yusoff MA, Ali R. \& Yaacob AR. (2019). A Note on Non-Volant Small Mammals of Pulau Pangkor, Perak, Malaysia. The Malaysian Forester 82 (1): 301 $-304$.

Nakagawa M, Miguchi H, Sato K, Sakai S. \& Nakashizuka T. (2007). Population Dynamics of Arboreal and Terrestrial Small Mammals in a Tropical Rainforest, Sarawak, Malaysia. The Raffles Bulletin of Zoology 55(2): 389-395.

Nor MS. (2001). Elevational diversity patterns of small mammals on Mount Kinabalu, Sabah, Malaysia. Global Ecology and Biogeography 10:41-62.

Oswald CD. \& Flake LD. (1994). Bait formulation effectiveness in livetrapping small mammals in eastern South Dakota. Proceedings of the South Dakota Academy of Science 73: 101-108.

Parrott M., Chhin S., Hun S., Chheang S. \& Furey N. (2014). A small terrestrial mammal survey and analysis of bait consumption at Bokor National Park, Cambodia. Cambodian Journal of Natural History 2014: 1923.

Patergnani M, Gras LM, Poglayen G, Gelli A, Pasqualucci F, Farina M. \& Stancampiano L. (2010). Environmental influence on urban 
rodent bait consumption. Journal of Pest Sci 83: 347-359.

Patric E. (1970). Bait preference of small mammals. Journal of Mammalogy 51(1): 179-182.

Payne J, Francis CM. Phillipps K. (1985). A field guide to the mammals of Borneo. The Sabah Society and World Wildlife Fund Malaysia, Kota Kinabalu.

Pervez A. (2007). Laboratory Evaluation of some Additive Poison Baits for Controlling Commensal and Field Rodents. Pakistan J. Zool. 39 (1): 35-43.

Rahelinirina S, Rajerison M, Telfer S, Savin C, Carniel E. \& Duplantier JM. (2017). The Asian house shrew Suncus murinus as a reservoir and source of human outbreaks of plague in Madagascar. PLoS Neglected Tropical Disease 11(11): e0006072.

Schlötelburg A, Jakob G, BellingrathKimura S. \& Jacob J. (2018). Natural bait additives improve trapping success of common voles, Microtus arvalis, Applied Animal Behaviour Science 208: 75-81.

Schnurr JL, Canham CD, Ostfeld RS. \& Inouye RS. (2004). Neighborhood Analyses of Small-Mammal Dynamics: Impacts on Seed Predation and Seedling Establishment. Ecology 85(3): 741755.

Shafi MM, Pervez A, Ahmad S. \& Ahmed SM. (1990). Role of some taste additives to enhance poison bait acceptance in the black rat, Rattus rattus. Tropical Pest Management 36 (4): 371-374.

Starr C, Nekaris KAI. \& Leung LKP. (2012) A comparison of three survey methods for detecting the elusive pygmy slow loris
Nycticebus pygmaeus in Eastern Cambodia. Cambodian Journal of Natural History123-130.

Stickel LF. (1948). Effect of bait in live trapping Peromyscus. Journal of Wildlife Management 12: 211212.

Stokes VL. (2012) Trappability of introduced and native rodents in different trap types in coastal forests of south-eastern Australia. Australian Mammalogy 35: 49-53.

Takács S, Musso AE, Gries R, Rozenberg E, Borden JH, Brodie B, Gries G. (2018). New food baits for trapping house mice, black rats and brown rats. Appl Anim Behav Sci 200: 130-135

Weihong JI, Veitch CR, \& Craig JL. (1999). An evaluation of the efficiency of rodent trapping methods: the effect of trap arrangement, cover type, and bait. New Zealand Journal of Ecology 23(1): 45-51.

Woodman N, Timm RM, Slade NA. \& Doonan TJ. (1996). Comparison of Traps and Baits for Censusing Small Mammals in Neotropical Lowlands. Journal of Mammalogy 77(1): 274-281.

Yusof MA, Ishak SN, Md. Nor S, Mohd. Sah SA, Azhari NN, Neela VK, Mohamed NZ. \& Mohd-Taib FS. (2019). Community Diversity and Prevalence of Leptospira sp. among Small Mammals in Urban, SemiUrban and Recreational Forest in West Peninsular Malaysia. EcoHealth 16: 260-274.

Zakaria M, Silang S. \& Mudin R. (2001). Species Composition of Small Mammals at the Ayer Hitam Forest Reserve, Puchong, Selangor. Pertanika Journal of Tropical Agricultural Science 24 (1): 19-22. 